\title{
Abulai Khan's Understanding of Eastern and Southern Kazakh Pasturelands in a 1760 Letter to the Qing Court
}

\author{
BAKHYT EZHENKHAN-ULI \\ L. N. Gumilyov Eurasian National University \\ Volume 15, 2018 \\ Special Issue: Manchu in Transregional History
}

This article deals with a Manchu translation version of a letter by Abulai Khan addressed to the Qianlong emperor of the Qing dynasty in 1760. An in-depth source analysis of the letter and other relevant historical documents shows that the Kazakhs, led by Abulai Khan, sketched out a conceptualization of the rough boundaries (ujan) of their pasturelands at that time, and that these boundaries covered the region east and south of Lake Balkash. By asking the Qing emperor to send back a red-sealed edict, the Kazakhs even tried to urge the Qing court to officially approve these boundaries. This leads us to question the dominant view that the region east and south of Lake Balkash was primarily an object of bipolar territorial rivalry between the Qing Empire and Russia.

从阿布㐘汗1760年致清廷的一份信中看其对于哈萨克草原东部和南部牧界的 理解

Bakhyt Ezhenkhan-uli巴哈提・依加汉

列. 尼.古米列夫欧亚国立大学

摘要

本文考察了阿布㐘汗1760年致清朝乾隆皇帝一份信的满文译本。对该信及相 关历史文献所作的深层分析结果显示, 阿布麥汗率领的哈萨克人在当时已形 成有关其牧地大致边界的概念, 这一边界囊括了巴尔喀什湖东岸和南岸的地 域。通过请求清朝皇帝给予其盖有红印的相关谕旨, 哈萨克人试图从清廷获 得关于该边界的官方认可。这一史实令我们不由质疑 “有关巴尔喀什湖以东 以南的领土争端一直都只是清朝和俄国二者之间的事务”这一盛行观点的合 理性。 
從阿布賚汗1760年致清廷的一份信中看其對於哈薩克草原東部和南部牧界的 理解

Bakhyt Ezhenkhan-uli巴哈提·依加漢

列.尼·古米列夫歐亞國立大學

摘要

本文考察了阿布賚汗1760年致清朝乾隆皇帝一份信的滿文譯本。對該信及相 關歷史文獻所作的深層分析結果顯示, 阿布賚汗率領的哈薩克人在當時已形 成有關其牧地大致邊界的概念，這一邊界囊括了巴爾喀什湖東岸和南岸的地 域。通過請求清朝皇帝給予其蓋有紅印的相關諭旨, 哈薩克人試圖從清廷獲 得關於該邊界的官方認可。這一史實令我們不由質疑 “有關巴爾喀什湖以東 以南的領土爭端一直都只是清朝和俄國二者之間的事務”這一盛行觀點的合 理性。

\section{Introduction}

Qing-era Chinese writings and Manchu archival documents both explicitly confirm that claims to sovereignty over the Tarbagatai region was one of the very first made by Kazakh envoys to the Qianlong emperor in the autumn of 1757 . According to these sources, the envoys dispatched by Abulai Khan, Abulpeyiz Sultan and Qabanbai batïr, leaders of the Middle Horde Kazakhs, put forward the claim by saying: "Tarbagatai - it is our former pastureland. We wish that your majesty show goodwill and give the land to us." Despite being annoyed by such a claim, the Qianlong emperor treated the territorial issue as a chip for bargaining with the Kazakhs. His offer to Abulai was: "If you capture and hand over Amursana ${ }^{1}$ to me, I will surely give over the land to you."

Qianlong's reaction to the Kazakhs' territorial claim over the Tarbagatai region in 1757 shows us that, at this early stage of the Kazakh-Qing relationship, the Qing court had not yet formed a clear and specific policy over the territorial issue in its western borderlands. At the same time, the Kazakhs' understanding of their territory is also interesting here. The view that Zhetïsu ("Seven Rivers," latterly in Russian Semirechie) and Tarbagatai belonged to the Kazakhs was one of the crucial facts that led the Kazakhs to march east into those regions and then to establish an close relationship with the Qing Empire in the second half of the eighteenth century. ${ }^{3}$ But, contrary to the Kazakhs'

1. Amursana was one of the Zunghar leaders who had first helped the Qing army to overthrow Dawachi, the last khan of the Zunghar state. He then rebelled against his Qing ally in 1755-1757.

2. Daqing Gaozong Chun (Qianlong) huangdi shilu 大清高宗純 (乾隆) 皇帝實錄, comp. Qinggui 慶桂et al. (1807; repr., Beijing: Zhonghua shuju, 1986; abbreviated GZSL), 548:9-10; Junjichu Manwen lufu zouzhe 軍機處滿文錄副奏摺, First Historical Archives of China, Beijing (abbreviated JMLZ), document 1855-022 (microfilm 01394-01406).

3. An episode on the Kazakh-Qing frontier in 1757 also tells us something about the attitudes of the parties involved in this 
desire to return to their pasturelands in the east, the Qing empire created and began to implement a more assertive frontier policy in 1760s, in which the so-called Hasak hešen or Hasak jecen ("Kazakh border") was already set flatly to the west of the AyagusBalkash-Chu line. Kazakhs were supposed to be restricted to the "other side" (the west side) of the Hasak jecen. ${ }^{4}$ This new policy actually led to a paradox within Qing imperial discourse concerning its relationship with Kazakhs: on the one hand, it claimed that "all the Kazakhs have become the albatu (subjects) of the Qing"; on the other hand, the Kazakhs in Tarbagatai and Zhetïsu regions were treated as intruders or "speculators" who

territorial issue. The Kazakh chieftain Kozhabergen battled Qing forces in 1756 together with Amursana in the Esil-Nura region and then led his people eastward to the Tarbagatai region. The following year, he encountered Qing forces upstream of Yar (on the Urzhar River in modern Kazakhstan) and asked the Qing generals several times if Qing troops would stay at or leave the place where they camped. The Qing generals answered him by saying, "If Amursana is captured in the morning, our army will retreat immediately at evening towards places such as Erenkabirga and Ili." Memorial by Zhaohui 兆惠, dated Qianlong (QL) 22.07.13 (August 27, 1757), in Zhongguo diyi lishi dang'anguan 中國第一歷史檔案館 and Zhongguo bianjiang shidi yanjiu zhongxin 中國邊疆史地研究中心, eds., Qingdai Xinjiang Manwen dang'an huibian 清代新疆 滿文檔案彙編 (Guilin: Guangxi shifan daxue chubanshe, 2012; abbreviated QXMDH), 24: 255-73; Kazakh translation in B. Ezhenkhan-uli, Қожаберген батыр - 1756-1767 жылдарда қалыптасқан мәнжу-қытай мұрағат құжаттары негізінде (Алматы: «Арыс» баспасы, 2017), 149-73.

4. As early as 1757, Nusan, the Qing envoy to Abulai's horde, tried to draw out a Hasak hešen in a memorial (QXMDH, 27: 207-8). This document has been studied in Jin Noda, The Kazakh Khanates between the Russian and Qing Empires: Central Eurasian International Relations during the Eighteenth and Nineteenth Centuries (Leiden: Brill, 2016), 157-58; and Onuma Takahiro 小沼孝博, Shin to Chūō Ajia sōgen: Yūbokumin no sekai kara teikoku no henkyō e 清と中央ア ジア草原: 遊牧民の世界から帝国の辺境へ (Tokyo: Tokyo daigaku shuppankai, 2014), 194-95. I also carried out some research independently on this document before becoming familiar with Noda’s work: B. Ezhenkhan-uli, “Қазақ үш жүзінің шеткері жерлеріндегі жер атаулары» атты Цин патшалық мұрағат құжатына тарихи-деректанулық талдаулар,” Қазақстан республикасының Ұлттық ғылым академиясының ХАБАРЛАРЫ 2 (2013): 28-35. I had originally intended to publish my research findings here but wish to revise my views further in light of Noda's work.

In Onuma, Shin to Chūō Ajia sōgen, this document is employed based on Noda's reading, and no transliteration of the text is given. There are still ambiguities concerning the text of the document that need further resolution, but it was only in the 1760s that the Qing court began mapping its western jecen (border) by drawing the Ayagus-Balkash-Chu line. According to two Manchu documents written on QL26.02.11 (March 17, 1761) and QL26.02.26 (April 1, 1761), respectively, copies of a certain Hasak. burut i jecen acaha ba i nirugan (Map of the Meeting of Kazakh and Burut Borders) were delivered to Qing borderland officials such as Dingchang 定長 and Agūi 阿桂 by the Grand Council. Zhongguo diyi lishi dang'anguan 中國第一歷史檔案館 and Hasake Dongfangxue yanjiusuo 哈薩克東方學研究所, eds., Qingdai Zhong-Ha guanxi dang’an huibian 清代中哈關係檔案彙編 (Beijing: Zhongguo dang'an chubanshe, 2006-2007; abbreviated QZHGDH), 1: 486-487, 498-99.

In my view, this map is the Manchu map, which has the Chinese title Yili Wuhaerlike Taleqi xuanzhi ji zhoubian yizhan kalun tu 伊犁烏哈爾裡克塔勒奇選址及周邊驛站卡倫圖 (Selected Sites for the Town [to Be Built in] Uharlik Talki of Ili and Its Neighboring Staging Posts and Karuns). A digital image of this map is available on the Information Management Platform (Xinxihua guanli pingtai 信息化管理平臺) of the First Historical Archives of China. The map itself is kept in JMLZ, record number 03-02-0179-1892-001, and is dated "the 8th month of the 26th year of the Qianlong reign." On the map, a red line named Hasak jecen was drawn close to the northern and western shores of Lake Balkash, and this Hasak jecen was shown intersecting the Burut jecen southeast of Lake Balkash. Obviously, this is an imagined "Kazakh borderline" rather than the actual "karun lines" that the Qing state wanted to construct in the 1760s. Given that the Qing state failed to establish relatively secure "karun lines" in the east, it would not be credible for Qing forces to think about patrolling all the way to the western shore of Lake Balkash.

For previous work concerning the formation of the Qing "borders" and "karun lines," as well as the eastward movements of Kazakh nomads, see: Saguchi Tōru 佐口透, Shinkyō minzokushi kenkyū 新疆民族史研究 (Tokyo: Yoshikawa kōbunkan, 1986), 375-435; Li Sheng 厉声, Hasakesitan jiqi yu Zhongguo Xinjiang de guanxi: 15 shiji-20 shiji zhongqi 哈萨克斯坦及其与中国新疆的关系：15世纪-20世纪中期 (Harbin: Heilongjiang jiaoyu chubanshe, 2004), 143-54; Onuma, Shin to Chūō Ajia sōgen, 192-99; Ezhenkhan-uli, Қожаберген батыр, 34-55, 62-103. 
need to be driven out from this Hasak jecen. ${ }^{5}$ Additionally, twentieth-century scholars reached their conclusions regarding Kazakh political geography based on the faulty assumption that the territorial issue concerning the modern Chinese-Kazakh borderland only came into question in Qing-Russian relations.

Although the Qing policy of expelling Kazakhs westward ultimately failed and the Kazakhs continued to dwell in the aforementioned regions, the influence of the Qing policy implemented in 1760s can be still felt today. One of the modern legacies of the historical Qing-Kazakh relationship is the dispute arising from the question of whether the territory east and south of Lake Balkash should be considered part of the Qing Empire? Since at least the 1960s, many historians have relied on the following understanding: "The region east and south to Lake Balkash, a territory of more than 40,000 sq. $\mathrm{km}$, had belonged to China during the Qing dynasty." 6

Beginning with the Sino-Soviet split in 1960s-1970s, China frequently raised the "historical injustice" that the land south and east of Lake Balkash was taken from China by Tsarist Russia, and then by the Soviet Union, through an "unequal" treaty. Even in contemporary discourse, it is often assumed that this is a territorial issue concerning Russia and the Qing dynasty. For example, Peter C. Perdue has stated, "By 1760 the Qing had crushed the [Zunghar] state and exterminated the Zunghar people .... The outcome was the bipolar division of Central Asia between two empires, marked by a border delimited in treaty negotiations between the Chinese and Russians. The bipolar

5. This paradox appears rarely in discussions of the Qing-Kazakh historical relationship generally. Many scholars working from traditional Qing sources and influenced by Qing historical discourse describe the relationship as "three hordes of Kazakhs becoming the subjects of Qing." This kind of conclusion is generally rejected by both Soviet-era and current Kazakh scholars (see the bibliographic survey in Noda, Kazakh Khanates between the Russian and Qing Empires, 32-41). Traditional scholarship tends to explain this relationship with the conception of a "Chinese tributary system.” John King Fairbank, "A Preliminary Framework," in The Chinese World Order: Traditional China's Foreign Relations, ed. Fairbank (Cambridge, Mass.: Harvard University Press, 1968), 1-19; Saguchi Tōru 佐口透, 18-19 seiki Higashi Torukisutan shakaishi kenkyū 18-19世紀東トルキスタン社会史研究 (Tōkyō: Yoshikawa kōbunkan, 1963).

In contemporary scholarship, a new discourse around this relationship is emerging, within which two approaches deserve special attention. Takahiro Onuma develops a conceptualization of "ejen-albatu relationships to describe Qing relations specifically with Kazakh nomads. This is a somewhat ambiguous idea that Onuma himself defines it as "a system of diplomacy centering on the diplomatic protocols." (Jin Noda and Onuma Takahiro, A Collection of Documents from the Kazakh Sultans to the Qing Dynasty [Tokyo: Department of Islamic Area Studies, Center for Evolving Humanities, University of Tokyo, 2010], 86.) At the same time, Peter C. Perdue explains Qing-Kazakh political correspondence in this way: "I would rather call it a kind of intercultural language, serving multiple purposes for its participants . . . masking the different self-conceptions of its participants with formal expressions but allowing each, in different degrees, a measure of autonomy" (China Marches West: The Qing Conquest of Central Eurasia [Cambridge, Mass.: Harvard University Press, 2005], 403.) While both of these arguments are influential and relevant, a substantial number of ambiguities and obscurities concerning historical Qing-Kazakh relations remain to be explained and clarified, for which new sources are crucially needed.

6. Just some of the examples from the sea of the publications in which this historical conclusion is repeated: Shi Yuxin 史 宇新, “Bohuangyan zhizaozhe-guanyu Zhong-Su bianjie de ruogan wenti” 驳谎言制造者一关于中苏边界的若干问 题, Lishi yanjiu 历史研究 1974.1: 113-28; Zhongguo jin-xiandaishi 中國近現代史 (Beijing: Renmin jiaoyu chubanshe, 2002); Li Sheng 厉声, Hasakesitan jiqi yu Zhongguo Xinjiang de guanxi.

7. See the works listed above in note 6 . 
division effectively lasted from 1760 until the collapse of the Soviet Union."8

To depict the region east and south of Balkash Lake as primarily an object of bipolar territorial rivalry between the Qing Empire and Russia is to ignore the relevance of the sovereignty issue to the Kazakhs, who actually lived in this territory. This is anachronistic. Between 1760 and 1824, Russian colonial rule in a strict sense was still not established in the Kazakh steppe, so, if there were truly any territorial issue in the 1760 s, such an issue could not be considered a "bipolar division" between the Qing and Russia.

So, what did Kazakhs think about the territorial issue in 1760s, when the Qing empire formed and started implementing a more assertive frontier policy? With a historicalgeographic analysis of the Manchu translation of a letter from Abulai Khan-written in late November 1760, and received at the Qing court on February 10, 1760_I hope to shed new light on this topic.

\section{Abulai Khan's 1760 Letter to the Qing Court}

The letter has been published in the first volume of Qingdai Zhong-Ha guanxi dang'an buibian 清代中哈關係檔案彙編 (A Collection of Archival Documents on SinoKazakh Relations in Qing Dynasty Period, abbreviated QZHGDH), under the title, $A$ Letter [by the Kazakh Khan Abulai] Asking the Emperor to Issue an Edict. ${ }^{9}$ A document of the same title can be found in an earlier work, Qingdai bianjiang Manwen dang'an mulu 清代邊疆滿文檔案目錄 (Catalogue of Manchu-language Archival Documents on Qing Borderlands, abbreviated QBMDM), which gives archival data and a speculative date of composition. ${ }^{10}$

8. Peter C. Perdue, "Boundaries, Maps, and Movement: Chinese, Russian, and Mongolian Empires in Early Modern Central Eurasia," The International History Review 20.2 (June 1998): 263.

9. See QZHGDH, 1: 460-61, no. 198.

10. QBMDM, 6: 421. According to this collection, this document is numbered 1861-042 and is reproduced in microfilm 059-0546. 


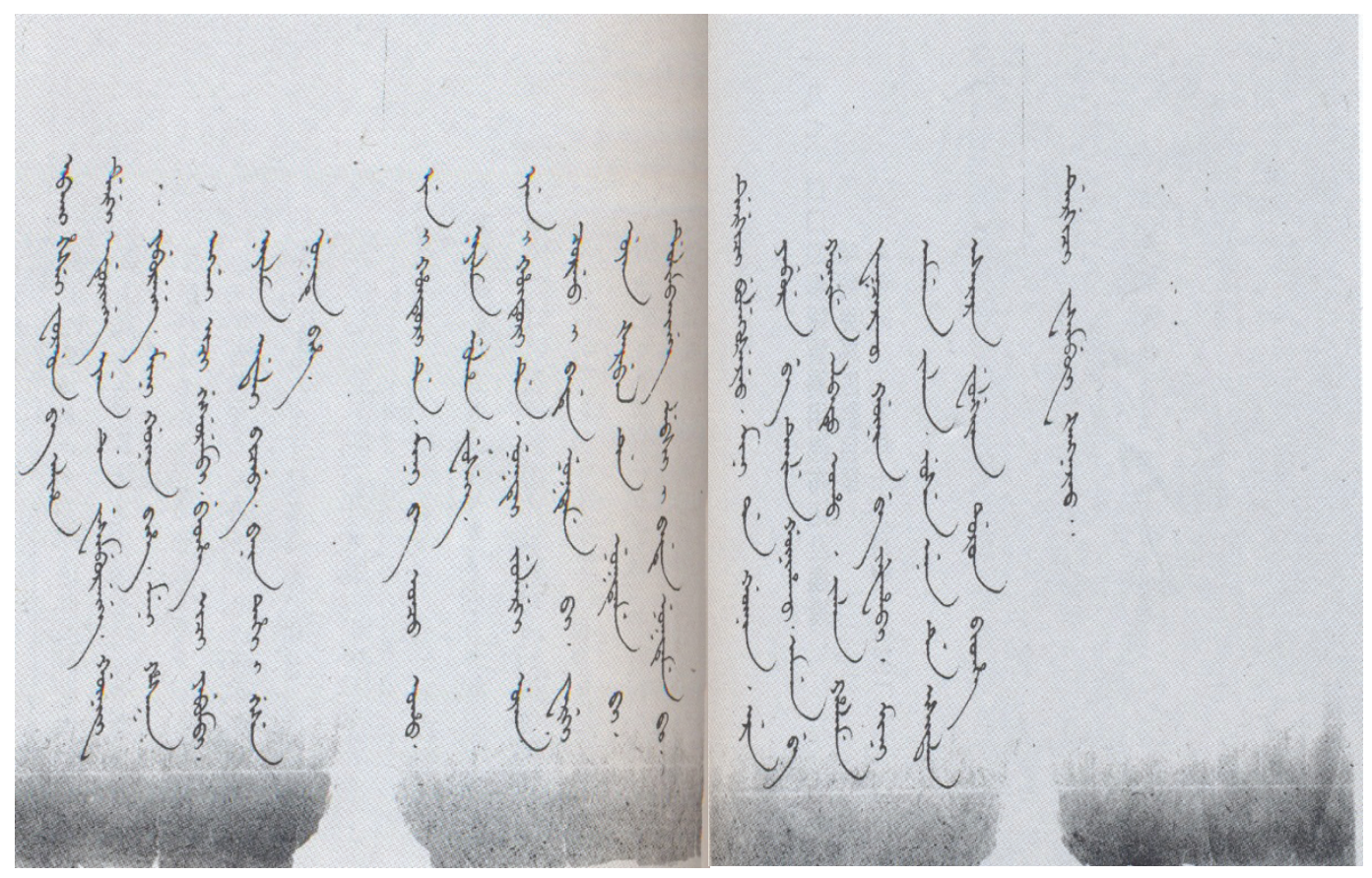

A Letter [by the Kazakh Khan Abulai] Asking the Emperor to Issue an Edict QZHGDH, 1: 460-61.

\section{Document Transcription}

abkai hesei forgon be aliha dergi enduringge ejen de wesimburengge. gūnifi yaburengge. mini gūnin bihe. meni hasak anggai ici gisurembi. bethe ici yabumbi. niyalma adali bicibe. banin tahi i gese nukte bihe. / ejen i hūturi de. mini ba onco oho. niyalma ulha fusengge. ejen i hūturi de. nuktei julergi ujan corgo i bade nukteme bi. wargi ujan šarabel de nukteme bi. dulimbaingge lebsi i bade nukteme bi. // dergici bulekušereo. mini da gūnin. ere yabure be teile gūnihakū. amaga be gūnime albatu oho. jalan halame fakcarakū gūnin be jafahabi. mini amaga jalan. juse enen de isitala 
asarara fulgiyan doron bithe /

dergici wasimbufi šangnareo.. //

\section{Translation}

To Your Majesty, the Great Ejen who rules by the will of Heaven:

The earlier decision regarding our movements was my own. ${ }^{11}$ Our Kazakhs say what they want to say, move where they want to move. Although they are like other human beings, they move about with characters just like those of wild horses. Relying on the blessing of the Ejen, my land has become wide and my people and livestock have increased. Relying on the blessing of the Ejen, the boundaries ${ }^{12}$ of my pasturelands have reached: south to Chorgo and west to Šarabel, and my central pastureland has become the area of Lepsi. Your penetrating judgment, which was my original inspiration leading me to be your albatu, was a consideration of the future rather than a thought only of the present. I hope that we will not separate from each other despite differences of generations, and for this sake, ask Your Majesty to issue a red-sealed edict that can be passed on and can be kept by future generations, by my posterity.

\section{Background of the Document}

Although no concrete date can be found within this translated Manchu version of Abulai Khan's letter, in their annotations to the document, the Chinese archivists suggest that the letter was written in "the 12th month of the 25th year of the Qianlong reign [January 1761]." ${ }^{13}$ The archivists reached such a conclusion only because the document was kept with the semimonthly packet of memorials (the yuezhe bao 月折包) for that date. We can determine a more accurate date for the letter by tracing related historical events.

There had been two Kazakh missions to the Qing court around this time, between the middle of 1760 and the beginning of 1761: the first one, headed by Quttibay and Atalay, arrived at the Qing court in the 5th month of the 25th year of the Qianlong reign (between June and July 1760); ${ }^{14}$ the second, headed by Jolbarïs Sultan, arrived at

11. Written "gūnifi yaburengge. mini gūnin bihe," this sentence seems to mean, "Formerly to think and [then] act is my own will," but such a translation makes no sense (see my discussion below).

12. In Manchu, the word here is written as ujan. Concerning the Chinese translation of this word, see $n 16$ below.

13. QZHGDH, 1: 460.

14. A batch of Manchu documents concerning this Kazakh mission have been published in QZHGDH, 1: 286-421. Kazakh translations of these documents are in: Б. Еженханұлы, Қазақ хандығы мен Цин патшалығының саясидипломатиялық байланыстары туралы қытай мұрағат құжаттары (Алматы: «Дайк-пресс», 2009), 1: 168-225. 
the Qing court and was received by the Qing emperor on the bingwu 丙午 day of the 1st month of the 26th year of the Qianlong reign (February 10, 1761). ${ }^{15}$ Thus this letter from Abulai Khan must have had something to do with one of these missions. The Qianlong emperor wrote these words in his edict to Abulai Khan and Abulmambet on February 19, 1761: "And now, in the letter submitted by your men Jolbarïs and others, there are such phrases as 'My southern border reaches Chuoerguo, my western border reaches Shalabole, and the center of my land is Lebuxi." 16 The place names mentioned by the Qianlong emperor here conform exactly with those mentioned in Abulai Khan's letter. This fact makes me believe that the letter of Abulai Khan discussed here was delivered by Jolbarïs Sultan, the Kazakh envoy to the Qianlong emperor, on February 10, 1761.

A small but not insignificant episode in Jolbarïs Sultan's mission should be mentioned. Chenggunjab, the Qing official who first received Jolbarïs Sultan at Uliyasutai, the Qing territory that bordered Kazakh land, mentioned in his memorial that, when they met, Jolbarïs Sultan said to him, "When we set out, our Abulai entrusted to me a letter he addresses to the great Ejen, and according to what Abulai asked me, I am going to bring it to Beijing myself and deliver it in person." ${ }^{17}$ According to a rule established by usage, most of the Kazakh letters addressed to Qing emperors were generally delivered as the "appendices" to Qing borderland officials" memorials. ${ }^{18}$ And most of the first Manchu translations of the letters (the original letters were either in Turki or in Western/Tödö Mongolian), as well as preliminary opinions and proposals concerning the matters touched by the letters, were put forward by the borderland officials who sent the memorials and the "appendices" to the court. In most such cases, the borderland officials' likes and dislikes influenced the emperor's attitude and imperial policy towards relevant events, even towards the senders of the letter themselves. So it is quite natural that sometimes Kazakh khans and sultans wanted the Qing emperor to learn directly what they, Kazakhs themselves, were thinking and wanting. Jolbarïs Sultan's assertion probably resulted from similar considerations. In all likelihood, because the envoy Jolbarïs Sultan did not give the letter to Chenggunjab but delivered it to the emperor in person, the original letter had nothing to which it could be attached and was consequently lost, surviving only in the Manchu translation kept as a separate and undated document. ${ }^{19}$

15. GZSL, 628:5, QL26.01 "bingwu."

16. GZSL, 628:18b-21a, QL26.01 “yimao.” The Chinese text connected with the place names reads, “今卓勒巴喇斯等所 奏, 又有南界綽爾郭, 西界沙喇伯勒, 中抵勒布西等語.” The word jie 界 (border, boundary) here stands for ujan in the Manchu translation of Abulai Khan's letter. Influenced by that Manchu translation, the geographical direction in this Chinese text is mistaken (see my discussion below).

17. QZHGDH, 1: 432-34, no. 183.

18. Noda Jin even treats this as a rather fixed formula for the flow of Kazakh correspondence (see Noda and Onuma, Collection of Documents from the Kazakh Sultans to the Qing Dynasty, 8). But in several cases Kazakh envoys themselves delivered letters to the Qianlong emperor, so the above-mentioned transaction process of the Kazakh letters need not be seen as a fixed system.

19. Most of the Kazakh letters that reached Qing court are now kept as "appendices" to the relevant Manchu officials' palace memorials in the First Historical Archives. 
Considering that Jolbarïs Sultan needed at least one month to reach Uliyasutai from the Nura-Esil region where Abulai Khan lived, Abulai Khan probably wrote the letter some time in late November 1760.

The hardest sentence to read in this document is the first one (see note 11). In my understanding, the "gūnifi yaburengge" part of this sentence has something to do with the Kazakh appeal for further eastward movement made by Quttibay and Atalay to the Qing court in the summer of 1760, just half a year before the letter discussed here was brought to the Qing court. As mentioned above, two major Kazakh diplomatic missions were dispatched to the Qing court during 1760-1761. The immediate cause of the missions was connected with a Kazakh-Qing border dispute caused by the "plunder" of Uriangqay Mongols, Qing subjects, by Qara-Baraq of the Naiman tribe. After the "plunder," Qing border officials had set out to intimidate Kazakhs into handing over Qara-Baraq to them. ${ }^{20}$ On the surface, the task of the missions was to seek forgiveness for Qara-Baraq's actions, but their goals were not limited to this. According to the sources, the Kazakh envoys announced the facts concerning Kazakh migrations to places in the Tarbagatai and Zhetisu regions and put forward their request to migrate further to the Ili (Qulja, or Eastern Ili) region. Concerning the Kazakh claims and requests regarding pastureland in the middle of 1760 , we have the following sources:

Under the records of the gengwu 庚戊 day of the 5th month of the 25th year of the Qianlong reign (July 9, 1760), an imperial edict to Abulmanbet, Abulai, Abulfeiz, and Khanbaba is preserved, in which Qianlong wrote, "In the memorial to the throne presented by your envoys I read such words: 'Nowadays, the lands that belonged to the Elute ${ }^{21}$ have become totally open, and the people who belong to our Abulpeyiz [the sultan] have settled down in these places: Tangatar - in Barlïq, ${ }^{22}$ Narbatu - in Temïr-Chorgo; Esenkeldi and Jolimbet, who belong to the Qara-Kerei tribe, have settled down in Tarbagatai; while Jarillqap, who belongs to Turumbai, herds his cattle in Altïnemïl, Qaratal, and Köksu. ${ }^{23}$ Now, would your majesty show your goodwill and permit Kazakhs to extend their pastureland to the $\mathrm{Ili}^{24}$ region?"'25

Under the records for the xinwei 辛未 day, directly following the gengwu 庚戊 day mentioned above, there is a similar account in which we read: "In the memorial to the throne presented by Kazakh envoys Quttibay and Atalay, there are such words that 'the

20. Concerning this event, see: GZSL, 602:3b-4b, QL24.12 “jimao”; 602:17, QL24.12 “bingxu”; 602:23a-24a, QL24.12 "gengyin”; 602:25a-26a, QL24.12 “xinmao”; 603:6b-7a; 607:1b-2a, QL25.02 “xinmao”; 607:6, QL25.02 “jiawu”; 607:9, QL 25.02 "bingshen." See also the sources from the GZSL and Manchu archival documents referenced in nn25, 32 below. 21. Elute 厄魯特, a Chinese equivalent for Manchu “Ület," a name by Manchus referred to the Oirats (Zunghar Kalmuks).

22. Modern Baerluke 巴爾魯克 Mountain, Xinjiang, China.

23. All of these places are in present-day Eastern Kazakhstan oblast, Kazakhstan.

24. This refers to the eastern Ili region under the control of the Qing Empire.

25. GZSL, 613:13b-17a.The rendering of Kazakh proper names is based on the Manchu text of the imperial edict. A full version of the edict in Manchu is given in QXMDH, 36: 350-56. But the date of this document is given incorrectly there as "the $2 \mathrm{~d}$ month of the 24 th year of the Qianlong reign." 
lands of the [former] Elute have become totally open. Of our Kazakhs, there are people who have migrated to Tarbagatai, Köksu, Chorhun, ${ }^{26}$ Barluk, and Altïnemïl. All of us are the servants of the emperor, the son of Heaven, so will your majesty show your goodwill and permit the Kazakhs to expand their pastureland to the Ili region?"'27

It is obvious that when the Kazakhs put forward the above claims in the summer of 1760 , they did so because they were still encouraged by the good relationship between themselves and Qing forces, established when the Zunghar remnants had been treated as common enemies by both parties in the 1750s. They believed that this general Qing policy would be sustainable. But the situation had changed by 1760: the Qing "pacifying" enterprises in Zungharia had achieved their basic goal, and there was no need any longer for Kazakh cooperation in the vast steppe battleground. So it is quite understandable that the Qing court would turn down the requests put forward by Quttïbay and Atalay, Kazakh envoys in mid-1760. In his edict addressed to the Kazakh khan-sultans, Qianlong expressed his discontent with the requests, and he ordered his borderland officials to "expel the Kazakhs who entered the regions mentioned."28

Half a year after Quttibay and Atalay's mission, Abulai Khan again sent out his envoys, this time headed by Jolbarïs Sultan. According to the above-mentioned memorial of Chenggunjab, ${ }^{29}$ Jolbarïs Sultan's mission was sent by Abulmambet, Abulai, Khanbaba, To $\gamma$ zhan, Bolat, Abulpeiz, Dayï, Saniyaz, and Batïr, namely by all three branches of the Middle Horde Kazakh Töre (the so-called "Chingizid") lineages that had established political relationships with the Qing court. ${ }^{30}$ Abulai khan's letter, brought to the Qing court at this time, shows that the Middle Horde khans and sultans had realized the changing mood of the Qing court and had modified their strategy by not mentioning their plan to move to the Ili (Qulja) region. Now they only insisted on a Qing affirmation of their ownership of the pasturelands they themselves actually dwelt on.

But the Qing emperor also turned down the request of the Kazakh mission headed by Jolbarïs Sultan. We read in the veritable records of the Qianlong emperor (abbreviated GZSL) that, nine days after receiving the Kazakh envoys, the Qianlong emperor issued his edict to Abulai and Abulmambet, saying: "All the lands mentioned here ${ }^{31}$ formerly belonged to the Elute. Judging by your envoys' vague statements, you covet these lands. It shows furthermore that you have a speculating mentality .... I will certainly not confirm [what your envoys asked of me]." ${ }^{32}$ Instead of "confirming" what the Ka-

26. Written in the text as Choerhun 綽爾渾. If this is not a corruption, it should be considered a version of the place name Chorgo.

27. GZSL, 613:17b-19a, QL25.05 “xinwei."

28. GZSL, 613:17b-19a, QL25.05 “xinwei."

29. See n19.

30. The lineages of the people who sent Jolbarïs Sultan as their envoy can be found in Songyun 松筠, Qinding Xinjiang shilüe 欽定新疆識略 (Wuyingdian edition, 1821), abbreviated XJShL.

31. See n16 above.

32. GZSL, 628:18b-21a, QL26.01 "yimao.” 
zakhs claimed, the Qianlong emperor and his borderland officials decided to be tougher on the so-called "speculators." As mentioned above, Qianlong delivered a newly-drawn map about the Hasak jecen and Burut jecen to the Qing officials in Urumchi and Ili for their reference and affirmed the officials' suggestion for carrying out a punitive policy towards the Kazakhs who crossed the perceived Hasak jecen of Ayaguz-Balkash-Chu. Qianlong issued the relevant edict, saying, "Kazakhs are insatiable. I am issuing this edict to confirm the suggestion submitted by Mingšui and others, that is: to pillage the Kazakhs and their herds and to capture and take back their chieftains - you may even capture Abulai himself." ${ }^{33}$ This gave Qing borderland officials an imperially sanctioned carte blanche to plunder the livestock, especially horses, of ordinary Kazakh nomads who crossed the Hasak jecen.

This second rejection by the Qing court of the Kazakhs' claim of ownership over the pasturelands in the east, as well as the tough frontier policy implemented by Qing borderland officials against the Kazakhs, led to a larger Kazakh mission to the Qing court the following year, in which not only the Middle Horde but also all of the Little Horde Kazakh Töre lineages were involved. ${ }^{34}$

\section{Notes on Place Names in the Document}

Geographical directions in this Manchu translation of Abulai's letter: Three place names--Chorgo, Šarabel and Lepsi--are mentioned in the Manchu translation of the letter. Of them, Lepsi, described as "the center of my land," is undoubtedly connected with the river of the same name in modern Almaty oblast, Kazakhstan. A river that emptied into Lake Balkash, Lepsi can be found in several eighteenth-century Qing Chinese and European maps. ${ }^{35}$ What we need to locate are the other two place names. Before we turn to these names, let us first briefly survey the geographical conception contained in the letter's Manchu translation.

As we read in this Manchu translation, Abulai Khan was asking that the Qing em-

33. The edict can be found in the Manchu palace memorial written by Mingd'ui, the Ili jiangjun, on QL 27.12.20 (February 2, 1763). See QZHGDH, 2: 157-58, no. 60.

34. Due to space limitations, I will leave the discussion of historical sources concerning the Kazakh mission to the Qing court during 1762-1763 for another article.

35. In the Qianlong Map drawn in the 1760s, the river's name is written as Lebuxi 勒布錫 or Lebushi 勒布什. See the two versions of the map: that kept in the Bibliothèque nationale de France, GE D 25949 (1) RES; and the version in the First Historical Archives of China (Wang Qianjin 汪前進and Liu Ruofang 劉若芳, eds., Qingting san da shice quantuji 清廷三大實測全圖集 [Beijing: Waiwen chubanshe, 2007], folio Qipai Xi er). With respect to the European map, Strahleberg's Map of Siberia, drawn in the 1720s, shows the relevant place name recorded as "Lepische." (Philip John von Strahleberg, An Historico-Geographical Description of the North and Eastern Part of Europe and Asia; but More Particularly of Russia, Siberia, and Great Tartary both in Their Ancient and Modern State: together with an Entire New Polyglot Table of the Dialects of 32 Tartarian Nations . . . Faithfully Translated into English [London: W. Innys and R. Manby, 1738], front map). 
peror acknowledge the rough outline of the Kazakhs' pasturelands by issuing him an official document to be passed down to his future generations. But it would not be reasonable to think that, by indicating the center of his territory as Lepsi, on the east side of Lake Bakash, he needed Qing acknowledgement that lands to the west of Lepsi (i.e., west of Lake Balkash) as his territory. I believe that the Manchu translator confused his directions here, and what led to such confusion is nothing other than difference of the conceptions of geographical directions between Turkic people and the MongolManchus: Turkic people determine their directions facing eastward, while MongolManchus do so facing southward. In other words, when Turkic people use the words "left" (sol) and "right" (oy) in the geographical sense, they mean "north" and "south," while in Mongolian-Manchu these words mean "east" and "west" respectively. ${ }^{36}$

This conceptual difference caused quite a number of serious problems in Qing-era sources, as well as in later literature concerning the history of the Kazakhs. For example, some Chinese-language Qing documents list as the "Western section of Kazakhs" (Hasake xibu 哈薩克西部) the Great Horde Kazakhs near Tashkent, who nominally belonged to Abuliz the puppet khan but were in fact under the control of Töle-bi. ${ }^{37}$ For this reason, those Kazakhs have been wrongly identified by many researchers with the Little Horde Kazakhs or the "true western Kazakhs" since the Qing dynasty. ${ }^{38}$ Tracing the origin of this misunderstanding, we find that it began in a Manchu-language palace memorial by Bandi, the Qing general who first met with the envoys from this Kazakh group on the 12th day of the 8th month of the 20th year of the Qianlong reign

36. We read in the Zhou History that "the Tujue Kaghan opens the door of his horde eastward, because he worships where the sun rises” (可汗 ... 牙帳東開, 蓋敬日之所出也), while in the old Tukic inscriptions we find that the word ilgärü means "to the front, to the east" and the word kedin means "back side, west." Zhoushu, ch. 50; Академу наук CССР, Институт Языкознания, Древнетюркский словарь (Денинград: “Наука,” Ленингр. отд-ние, 1969), $208,283$.

It is obvious that there was a tradition of deciding orientation by facing eastward in the Old Turkic culture (some researchers consider it a borrowed cultural element rather than originally part of Turkic culture; D. Sinor and S. G. Klyashtorny, "The Türk Empire," in History of Civilizations of Central Asia, vol. III, The Crossroads of Civilizations: A.D. 250 to 750, ed. B. A. Litvinsky, Zhang Guang-da, and R. Shabani Samghabadi [Paris: UNESCO Publishing, 1996], 330). We know that yurt doors of the Kazakh nomads always opened eastwards, and they indicated "south" as on ("right") and "north" as sol ("left"). These facts show that the old Turkic tradition was followed by Kazakhs. In Mongolian, emün ("front") means "south" (emüne means both "in front" and "on the south side"), aru means both "back" and "north," baragun means both "right, right hand” and "west” (G. J. Ramstedt, Введение в алтайское языкознание [Москва: Изд-во иностранной лит-ры, 1957], 64, 267, 117). In the banner system of Inner Mongolia, the "left banners" indicate eastern parts and the "right banners" indicate the western parts of administrative units. In Manchu, dergi means "upper," "left," and "east." For example, one of Nurhachi's capitals was named Dergi Hecen, "Eastern Capital," while wargi means "west," "right side," and "under." See L. M. Gorelova, Manchu Grammar (Leiden: Brill, 2002), 29; Jerry Norman, A Comprehensive Manchu-English Dictionary (Cambridge, Mass.: Harvard University Asia Center, 2013), 401.

37. A Manchu document about the Töre (the so-called "Chigizid") lineages of the three Kazakh hordes demonstrates the selfidentification of this part of the Kazakhs as the "Great Horde" and "Southern Kazakhs." It is noteworthy that Jolan, son and envoy of the aforementioned Kazakh leader Töle-bi, gave this information to the Qing court. See QZHGDH, 1: 18082, No. 75. A Kazakh language translation with notes of this document can be found in: Еженханұлы, Қазақ хандығы мен Цин патшалығының саяси-дипломатиялық байланыстары туралы қытай мұрағат құжаттары, 1: 120-24.

38. The Zhigong tu—an ethnographical picture album compiled during the Qianlong reign—provides one example of the incorrect identification of these Kazakhs as the "Western section of Kazakhs." See Fuheng 傅恆 et al., eds., Huangqing zhigong tu 皇清職貢圖 (Shenyang: Liaoshen shushe, 1991), ch. 2. 
(September 17,1755$)$ and submitted the memorial after the meeting. ${ }^{39}$ This term was then adopted in a series of Manchu documents written in 1757, such as the palace memorials of Fude and other Qing officials who, when pursuing the Zunghar chieftain Kasakshira, encountered these Kazakhs near the city of Tashkent and helped the Kazakh envoys to depart for Beijing. But in most first-hand contemporary Chinese-language Qing archival documents and historical compilations, the term "Right (hand) section" (右部) instead of “Western section" (西部) was used to indicate those Kazakhs. ${ }^{40}$ This fact tells us that when the two parties encountered each other, the Kazakhs called themselves the "Right (hand) section of Kazakhs" and the term was misinterpreted by some Mongol-Manchu officials as "Western section of Kazakhs," following their own geographical conceptions. ${ }^{41}$

I believe that the same confusion must also have occurred when the letter under discussion was translated into Manchu and that the geographical directions mentioned in the original letter must be "eastern" and "southern" instead of "southern" and "western." Abulai Khan must have mentioned Chorgo as the "eastern" boundary and Šarabel as the "southern" boundary of his people's pasturelands.

So where were the eastern and southern boundaries of Kazakh pasturelands in 1760, according to Abulai Khan's understanding?

The eastern ujan (boundary) of Kazakh pastureland: Chorgo. As early as the 1760s, sources about Chorgo were collected by the Qing court, and we can find the relevant information in the Xiyu tongwen zhi 西域同文志 (Comparative Glossary of the Languages in the Western Regions, abbreviated XTZ) and the Xiyu tuzhi 西域圖 志 (Comparative Glossary of the Languages in the Western Regions, abbreviated XT).

39. JMLZ, 0448-001 (microfilm 012-2598). A Kazakh translation of the document can be found in: Б. Еженханұлы, Ж. Ошан, and С. Сұңғатай, Қазақстан туралы қытай дереутеселері, vol. 3, Цин патшалық мұрағат құжаттары (Алматы: Цин патшалық мұрағат құжаттары, 2006), 28-31.

40. QZHGDH, vol. 1, Manchu nos. 56, 57, 63, 67, 68, 84, 85; Chinese nos. 61, 66, 70, 71, 72, 74, 76.

41. The descriptions of Kazakh bu 部 (sections) in Qing sources are quite problematic, and they led to a number of confusions and misunderstandings concerning Kazakh social structure in the eighteenth and nineteenth centuries. Of these errors, the most popular and questionable is the identification of the three Kazakh bu in the Qing sources with the traditional Kazakh three jüz. As early as 1960, Paul Pelliot noticed the problem and mentioned that the xibu 西部 (western section) in the Xinjiang shilüe actually indicated the genealogy of Middle Horde Kazakh sultan Barak rather than the Little Horde Kazakh rulers. Boxihe 伯希和 [Paul Pelliot], Ka'ermeikeshi pingzhu 卡尔梅克史评注, trans. Geng Sheng 耿昇 (Beijing: Zhonghua shuju, 1994), 330-46.

In 1989, I tried to shed light on this problem by comparing transmitted Qing sources with the anthropological materials that I collected among Kazakhs living in the Chinese Ili region at that time. I showed that the so-called xibu is a variable, sometimes even self-contradictory, conceptualization (Bahati Yijiahan 巴哈提 依加漢 [B. Ezhenkhan-uli], “Xi Qing wenxian suoji “Hasake Xibu”” 析清文獻所記“哈薩克西部,” Yuanshi ji beifang minzushi jikan 元史及北方民族 史集刊 11 [1987]: 83-87). In my later work, this topic is touched upon again: Б. Еженханұлы, Ж. Ошан, and С. Сұңғатаймен, Қазақстан тарихы туралы қытай деректемелері, vol. 1, Саяхатнамалар мен тарихи-географиялық еңбектерден таңдамалылар (Алматы: «Дайк-пресс», 2005), 244n2, 302n2; Қожаберген батыр - 1756-1767 жылдарда қалыптасқан мәнжу-қытай мұрағат құжаттары негізінде (Алматы: Арыс баспасы, 2017). Noda Jin also gives a lengthy discussion of this problem, but some of Noda's statements could be improved. For example, he writes that the identification of the three bu with three jüz appeared "beginning with P. Pelliot"; this statement runs contrary to facts and needs to be revised. Noda, Kazakh Khanates between the Russian and Qing Empires, 144-80, quote from 153. 
In the section entitled "Place Names of the Northern Part of Tianshan" in the Xiyu tongwen zhi we read: "Chuoerguo 綽爾郭 - a Zunghar word, it means 'a pipe from which water can be drawn out.' Here in this place spring water flows out of a section of the earth, and it seems that the water flows out of a pipe. From this emerges the place name." ${ }^{\prime 2}$ The "Territory 4: Tarbagatai" section of the Xiyu tuzhi gives a different and more concrete description of this place: "Chuoerguo is located to the west of the Wulanhujier 烏藍呼濟爾 and north of Eerhechuke Mountain 鄂爾和楚克鄂拉. Its water is clear, and the pasture is flourishing. Previously, the tribe of Amursana lived at this place." ${ }^{43}$ From these descriptions we know that there were actually two place names connected with Chorgo, one a river and the other a pastureland somewhere west of Wulanhujier and north of Eerhechuke Mountain.

One of the landmarks here is the mountain Eerhechuke 鄂爾和楚克. According to the XTZ, this place "is located 400 li to the northeast of Baerluke 巴爾魯克 mountain ...."44 From Turkic "barluq" or "barlïq," meaning "abundant in," Baerluke is found on both Qing and modern maps under the same name. The concrete indication of the distance between Baerluke and Eerhechuke is crucial for determining where Eerhechuke is. On Qing maps, such as the various versions of the Qianlong shisanpai tu 乾隆十三 排圖 (The Qianlong-era Map in Thirteen Rows, cited subsequently as the Qianlong Map), we can find a mountain named Eerhechuer 鄂爾和楚爾 instead of Eerhezhuoke 鄂爾和楚克, which is located to the northeast of Baerluke at a distance similar to that mentioned in the XTZ. Kazakhs and Mongols in Xinjiang still call the mountain Orqasar. So we believe that the author of the XTZ made a mistake in using the character “-ke" (克) instead of “-er" (爾) at the end of the place name when he transcribed it.

For locating Chorgo, the most valuable information can also be found in the Qianlong Map. Here is the relevant content from the version of the map in the Bibliothèque nationale de France. ${ }^{45}$ The place names concerned are shown as:

No.1 - “Baerluke alin”巴爾魯克阿林, Barluq Mountain

No. 2 - “Eerhechuer alin” 鄂爾和楚爾阿林, Orqašar Mountain

No.3 - “Temuer-Chuoerhe alin” 特莫爾綽爾和阿林

No.4 - “Temuer-Chuoerhe bila” 特莫爾綽爾和比拉

42. Fuheng, Xiyu tongwenzhi, Minzu guji congshu 民族古籍叢書 ed., ed. Wu Fengpei 吳豐培 (Beijing: Zhongyang minzu chunbanshe, 1984), 1:16.

43. Fuheng et al., Xiyu tuzhi jiaozhu 西域圖志校注, ed. Zhong Xingqi 鐘興麒 et al. (Urumqi: Xinjiang renming chubanshe, 2002), 16.

44. XT, 333.

45. See Map No. 1 below. I copied this map with the permission of Bibliothèque nationale de France in November 2007. 


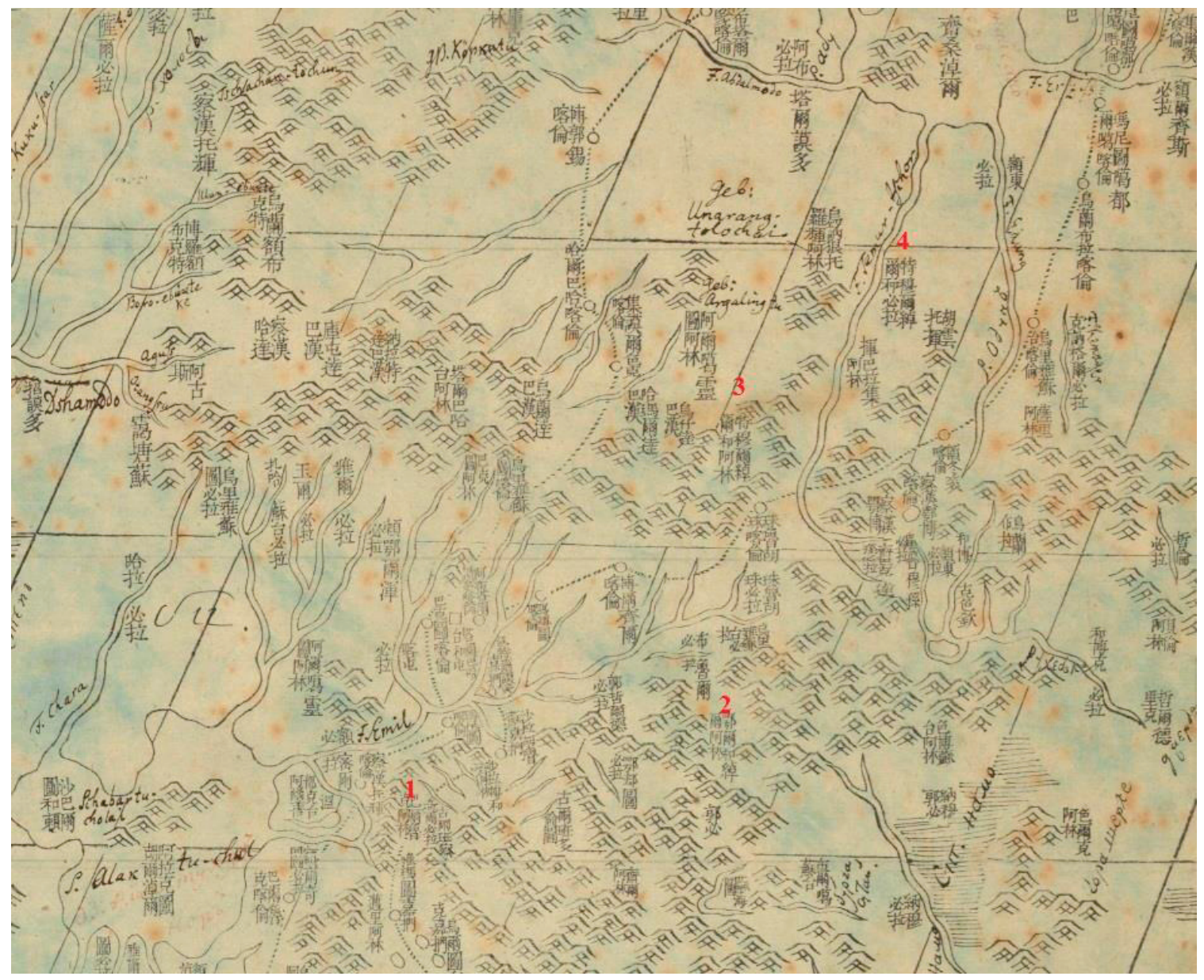

Map No. 1: Qianlong Map (detail). Source: BnF, GE D 25949 (1) RES.

According to the map, there are really two places to the north of Eerhechuer Mountain whose names contain the word Chorgo: “Tiemuer-Chuoerhe bila” 特莫爾綽爾 和比拉 and “Tiemuer-Chuoerhe alin” 特莫爾綽爾和阿林. Coming from Manchu, the second parts of the names ("bila" [=bira] and "alin") mean "river" and "mountain," respectively. The river that empties into Zaisan Lake (“Zhaisang noer” 齋桑諾爾 on the map) is still called Šor $\gamma$ a by Kazakhs today. Both the eighteenth-century Chinese transcription "Chuoerguo" (or "Chuoerhun" ${ }^{46}$ ) and the modern Kazakh Šor $\gamma$ a are derived from the Zunghar Mongolian word Chorgo. And from the fact that "TiemuerChuoerguo" can be replaced by "Chuorhun" ${ }^{47}$ we may say that, coming from TurkicMongolian "Temur / Temïr" (Iron), the first part of these place names ("Tiemuer") shown in the map is an adjective.

Locating the second Chorgo, namely the Temur-Chorgo Mountain, can also be

46. Concerning this form of the name, see GZSL, 613:17.

47. GZSL, 613:17. 
settled by information given in the Qianlong Map. On the map, it is located at a place to the north of two smaller rivers that formed as tributaries of the Emil River (額米 爾必拉) and to the west of Chahan-ebo 察漢鄂博. Kazakhs nowadays call the two tributaries of the Emil River Qara-Emil ("Black-Emil”) and Sarï-Emil ("Yellow-Emil”) and call the place to the northeast of the two rivers Sha $\gamma$ an-oba, which is apparently derived from Mongolian "Chagan-obo." The second Chorgo, or Temur-Chorgo Mountain, must therefore be the eastern branch of the Tarbagatai mountain range, which penetrates into modern Emin 額敏county (its local Mongolian name is “Dörbeljïn") and now forms a part of the borderline between the Republic of Kazakhstan and the People's Republic of China.

The southern boundary (ujan) of Kazakh pastureland: Šarabel (Saribel). The earliest Qing source in which this place name can be observed is the Yongzheng shipai tu 雍正十排圖 (The Yongzheng-era Map in Ten Rows). ${ }^{48}$ In the "Wupai xiwu" 五排西 五 ( $5^{\text {th }}$ Row, Western 5$)$ folio of the map there are such two place names (with numbers marking the place names added):

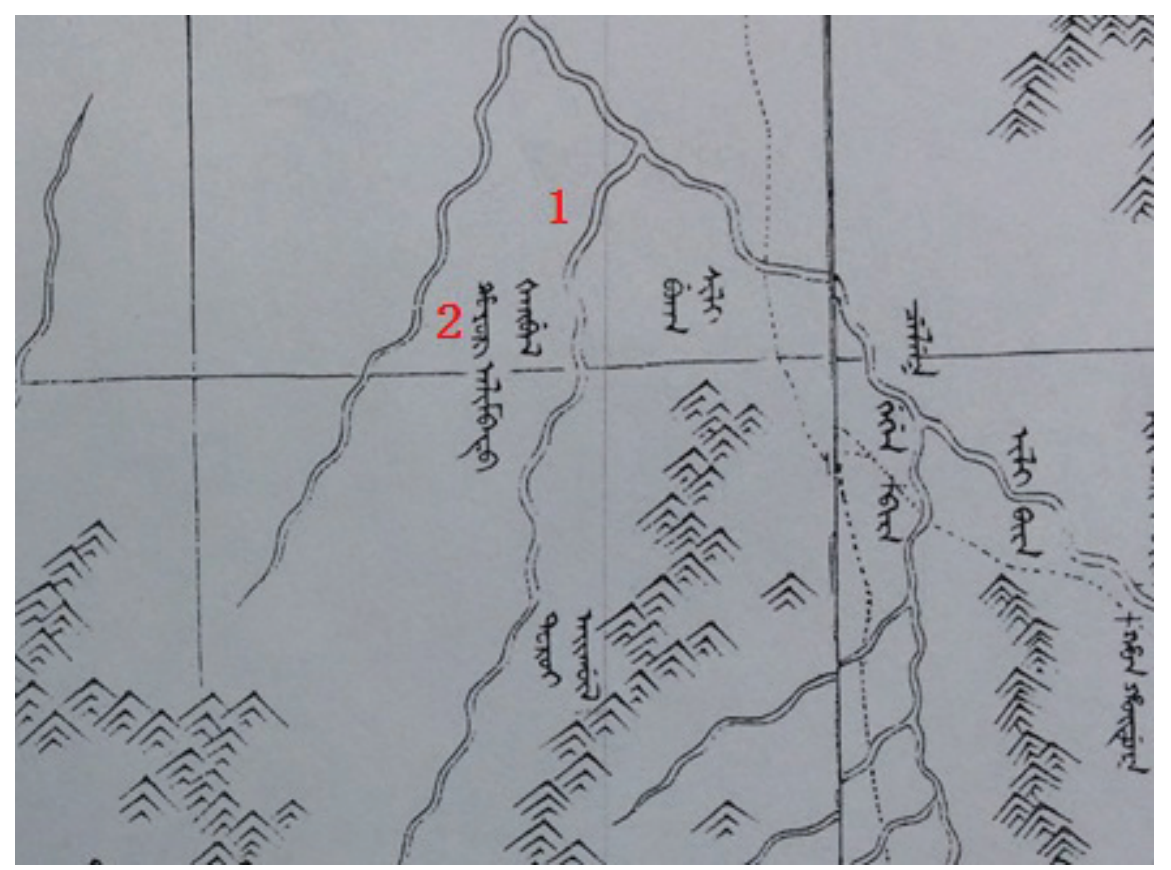

Map No. 2: Yongzheng shipai tu (detail). Source: Wang Qianjin and Liu Ruofang 2007.

No. 1 - "Šarbel"

No. 2 - "Hoyor Alimbatu"

48. See Qingting san da shice quantuji. 
The "Alimbatu" in place name No. 2 is obviously a corruption of "Alimatu," which came from "Almatu" or "Almaty," the name of the southern capital of modern Kazakhstan. The second part of the place name, hoyor, means "two" in Mongolian. So this is a Zunghar Mongolian name for the Almaty (Almatu) region in the $1730 \mathrm{~s},{ }^{49}$ while according to the map, Sarbel, place No. 1, is located to the east of Hoyor Alimbatu ("Two Almatu"). In the Chinese sources of the Yongzheng period, we find that there was a place name Xilabaier 西拉百爾mentioned together with Alimatu..$^{50}$ I take the name Xilabaier to be an early Chinese transcription of Šarbel (< Mon. Šarbel / Kaz. Sarïbel).

In the later Qianlong Map, ${ }^{51}$ Sarbel is transcribed into Chinese as Shaerboer 沙爾博 爾. ${ }^{52}$ Probably influenced by the citation from the Yongzheng shipai tu discussed above, in which $\breve{S} a r b e l$ is shown east of Alimatu, the Qianlong Map shows the location of Šarbel as follows (with numbers marking the place names added).

It is somewhere on the south side of the Ili River (place No. 5, name transcribed from Manchu into Chinese as Yili bila 伊犁必拉), east of Gurban Alimatu (place No. 2, name transcribed from Mongolian into Chinese as Guerban Alimatu 古爾班阿裡 瑪圖) and the Turgen River (place No. 3, transcribed from Manchu into Chinese as Tuergen bila 圖爾根必拉), and west of the Čelek River (place No. 4, name transcribed from Manchu into Chinese as Cheleke bila 撤勒克必拉).

These facts encourage us, however, to doubt the reliability of the location of Shaerboer (Šarbel) in the Qianlong Map. Firstly, the Qianlong Map shows it as the name of a certain river (the name is written across a river on the map). As a geographical term, bel may mean "hill," 53 "mountain pass," or "mountain slope" 54 in Turkic languages, but it is never used to indicate a river. Secondly, the fact that this $\breve{S}$ arbel is frequently mentioned together with Alimatu means that these two places are adjacent, while in the Qianlong Map they are separated by the Turgen River.

As mentioned above, this name was also written in Qianlong's edict in Chinese as Shalabole 沙喇伯勒. ${ }^{55}$ This appearance tells us that this place name was not completely unfamiliar to Qing scribes. We read in the Qing shilu and Pingding Zhungaer fanglüe 平 定準噶爾方略 that this very Shalabole is a key pass which connects the roads to Kash-

49. What is interesting is that this region is generally called the Three Almatu/Almaty" (Mongolian, Gurban Alimatu) instead of the "Two Alimatu" in most Qing sources. It seems to me that this Hoyor Alimatu ("Two Almatu") has something to do with the fact that there are two rivers that retain the name "Almaty" even today -the Ülken Almaty (Russian, Bol'shaya Almatinka, "Grand Almaty") and the Kï̌i Almaty (Russian, Malen’kaya Almatinka, "Little Almaty”).

50. Daqing Shizong Xian (Yongzheng) huangdi shilu 大清世宗憲（雍正）皇帝實錄 (Beijing: Zhonghua shuju, 1986), 107:14b-16b, YZ09.06, "bingwu" (July 18, 1731). According to this source, the Zunghar ruler Galdan-Tseren sent almost all of his 20,000 troops to Alimatu-Xilabaier to defend themselves from the “Kazakh state” (哈薩克國).

51. See Qingting san da shice quantuji.

52. In Qing-era Chinese, the character 爾 can be used to transcribe both the " $\mathrm{r}$ " sound and the "l" sound in foreign languages. Examples can be found in the place names mentioned above: Temur is transcribed特莫爾, while 額米爾 renders Emil.

53. Древнетюркский словарь, 93.

54. Қазақ ССР Ғылым академиясы Тіл мен әдебиет институты, Қазақ тілінің түсіндірме сөздігі (Алматы, 1959), 108.

55. See n15. 


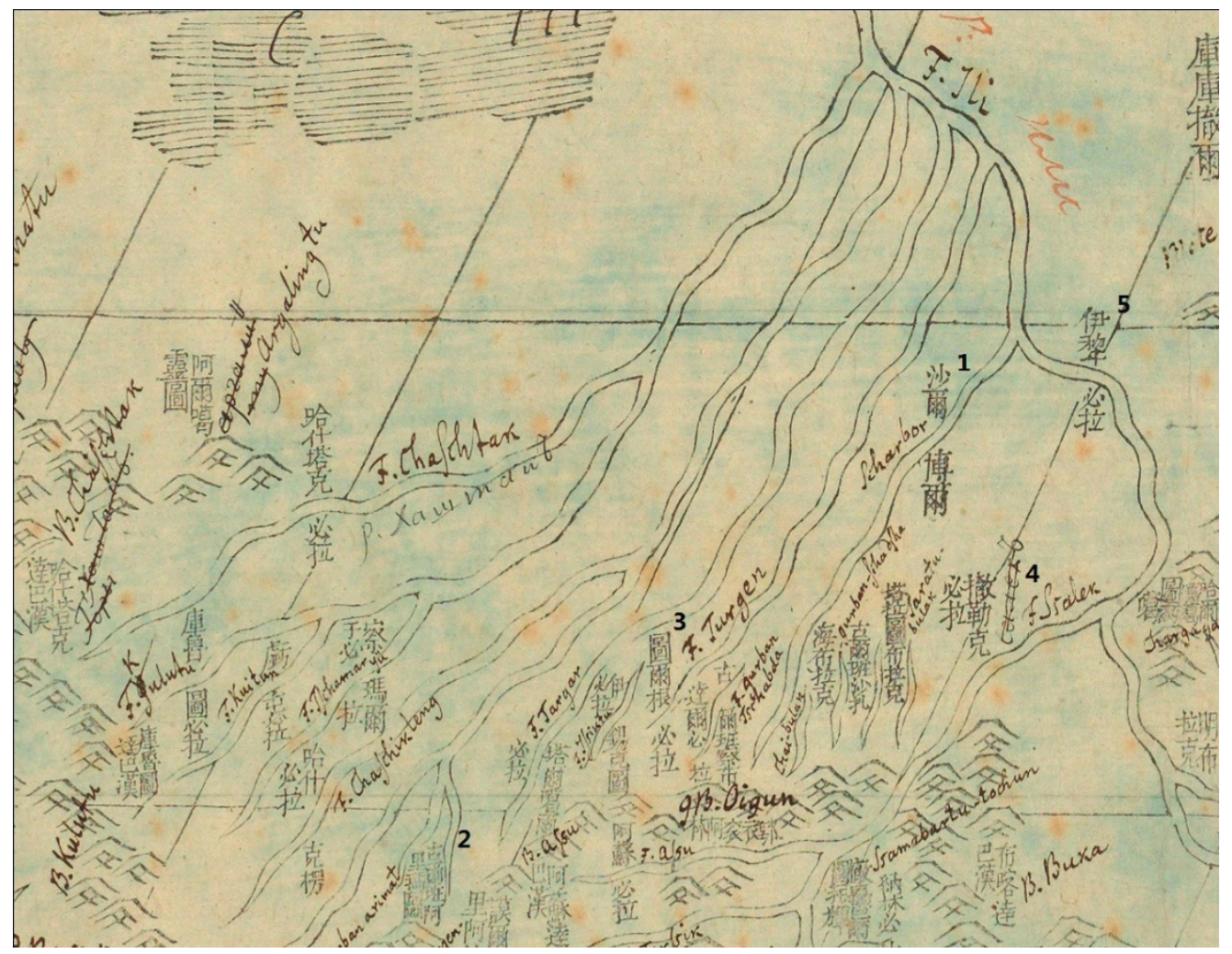

Map No. 3: Qianlong Map (detail). Source: BnF, GE D 25949 (1) RES.

gar, to Aqsu, and to the "Southern part of the Kazakhs." We read in these sources that a map which shows the road connecting Shalabole with Kashgar was even submitted to the Qianlong emperor. ${ }^{56}$ What is curious is that such an important place was not definitively located in any Qing Chinese language writing.

Yet, it does not mean that no relevant clues can be found. In the GZSL, we read: "The Kazakhs told Fude: 'If Amursana fled by passing over mountains such as the Aletanemier and Kulunkui, ${ }^{57}$ and through the place of Shalabole, he could go on to the territory of the Southern part of the Kazakhs.' Shalabole - it is the place where Baishiagashi resides." 58

Here, Shalabole is indicated as the pasture land of Baishiagashi 伯什阿噶什.

56. GZSL, 557:26b-27b, QL23.02, “kuiwei”; Pingding Zhungaer fanglüe, comp. Fuheng 傅恒 et al., ed. Xizang shehui kexueyuan Xizangxue Hanwen wenxian bianjishi 西藏社會科學院西藏學漢文文獻編輯室 (Beijing: Quanguo tushuguan wenxian suowei fuzhi zhongxin, 1990), zhengbian, 50:31-32.

57. Of these two places, the first one is undoubtedly the Altïnemil. Concerning the second, the Xiyu tuzhi gives this definition: "Kulongkui Mountain is 100 li to the southwest of Chagan-Bugutu (Ča $\gamma$ an-Bu $\gamma$ utu / Bu $\gamma$ itii). It is north of the Ili River . ... The Kuku-wusu (< Kök-usu / su) River originates at its north side.” Xiyu tuzhi jiaozhu, ch. 13.

58. GZSL, 512:6, QL21.05, "xinwei." 
From Qing writings, we know that Baishiagashi $\left(<\right.$ Bešagaš $\left.^{59}\right)$ was the chief of the $\mathrm{Zu}-$ nghar Doerbute (< Dörbüt) tribe. ${ }^{60}$ Early in their penetration of the Ili region, Qing forces treated Baishiagashi as an important figure, especially where Kazakh affairs were concerned. ${ }^{61}$ The situation of this tribe prior to the period under discussion can be found in Strahlenberg's Map of Siberia, drawn in the 1720s. ${ }^{62}$

Although a number of inaccuracies concerning the locations of some places can be observed, ${ }^{63}$ the information about the geographical distribution of Zunghar Kalmuks and Kazakhs in Strahlenberg's map is unique and very valuable. Ph. J. von Strahlenberg was a Swedish officer taken prisoner by the Russians at Poltava and sent to Tobolsk in 1711. During his captivity of more than a decade he collected information about neighboring regions and peoples, including the Oirats, and his knowledge about them should be reliable. According to the map, the Dörbüt Kalmuks (written as "Dœrbœet Kalmaki") lived in the place between two lakes, namely Lacus Issich Kul and Tchoi Lacus, and near a mountain called Kaschluh. Of the two lakes, the first one correspondents to modern Isikköl Lake in Kirgizstan. Although we don't know the origin of the name Tchoi (< "Chui / Chu"?) for the second lake, since rivers such as the Lepsi ("Lepische" on the map), Qaratal ("Kartal" on the map), and the three main tributaries of the Ili- the Kasch $[<$ Qash], Knigis [ $<$ Künes], and Takes $[<$ Tekes] —are shown emptying into it, it must be Lake Balkash, the lake also called that by other eighteenth-century cartographers. ${ }^{64}$ Despite being inaccurately drawn, the Kaschluh on Strahleberg's map most likely has something to do with the modern mountain Kastek, close to the present-day Kazakh-Kirgiz border.

It is interesting that in The Ballad of Abulai, a piece of Kazakh folklore collected by Ch. Ch. Valikhanov in the nineteenth century, the place name Saribel appears connected with the campaign of Abulai against the Kirgiz: ${ }^{65}$

59. The Manchu form of this name, which has a Turkic origin and literarily means "five trees," can be found in some Manchu archival documents, two of which I have translated into modern Kazakh: Цин патшалық мұрағат құжаттары, 18-22.

60. Xiyu tongwenzhi, 9:20.

61. Bandi, the Qing general who was in charge of the "pacification" campaign in the Ili region in 1755, mentioned in his palace memorial that "the followers of Baishiagashi (Bešagaš) constitute 3,000-4,000 households," and that "they are bordered by the Kazakhs . . . . They need protection from Kazakh plundering.” Pingding Zhungaer fanglüe, 1209-10.

A Manchu document tells us that in 1755 Bandi and other Qing generals in the Ili region were considering the use of Bešagašs forces to defend the Ili region from the Kazakhs. QZHGDH, 1:4-6; a Kazakh translation of this document can be found in: Б. Еженханұлы, Қазақ хандығы мен Цин патшалығының саяси-дипломатиялық байланыстары туралы қытай мұрағат құжаттары , 18-22.

62. See von Strahlenberg, An Historico-Geographical Description of the North and Eastern Part of Europe and Asia, front map. On this map, see Perdue, "Boundaries, Maps, and Movement," 281-84.

63. For example, Almaty River (written as Alamatum bolak) is shown as emptying into a lake ("Tschoi lacus," this should be Lake Balkash) instead of the Ili River, and it is located too far to the west.

64. For example, Renat's Map 1 calls this lake Balkash, while the Qianlong Map calls it Baerhashi. For information on Renat's Map 1, see Perdue, "Boundaries, Maps, and Movement," 280; about that in the Qianlong map, Asie centrale, in Bibliothèque nationale de France, GED 25949 (1) RES; Wang and Liu, Qianlong neifu yutu, in Qingting san da shice quantuji, folio Qipai Xi san.

65. Ч. Ч. Валиханов, Собрание сочинений в пяти томах (Алма-Ата: Glav. Red. Kazakhskoi sob. Entsiklopedii, 1984), 1: 261. The transcription and translation are mine. 


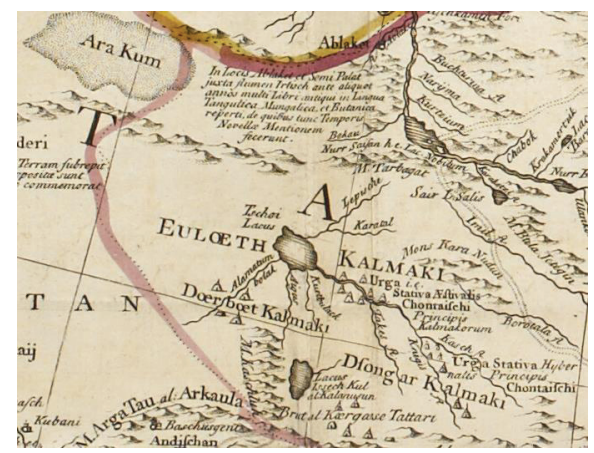

Map No. 4: Ph. J. von Strahlenberg's Map of Siberia (detail). Source: von Strahlenberg, An Historico-Geographical Description of the North and Eastern Part of Europe and Asia.

Original verses

ابلاى داى تقسرخان

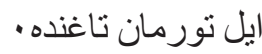

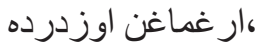

باياو جاتقان قرغزده ارزد برده

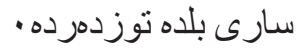

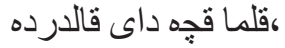

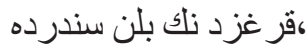

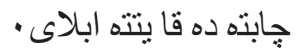

\section{Transcription}

Abïlayday taqsïr han ayil-turman ta aryïmajïn ozdïrdï, bayaw jatqan Qïryïzdi Saribelde tozdïrdï. Qalmaqčaday qaldïrdï, Qïr үïzdïn belin sïndïrdï, čaptï da qaytï Abïlay.

\section{Translation}

Being a majestic khan, Abulai got his steed saddled.

Galloping forward on his steed, he made the unprotected Kirgiz lose their wits at Saribel. Leaving them just like Kalmuks, he made Kirgiz surrender.

Having so campaigned, Abulai returned.

We believe that the name Saribel in this piece of folklore has something to do with the name Šarabel in the Manchu translation of Abulai Khan's letter discussed here. Firstly, the Kazakh word sarï ("yellow") is equivalent to the Mongolian word šara. Secondly, the information given in this ballad hints that, at some time before his campaign against the Kirgiz, Abulai had made the Kalmuks surrender to him at Šarabel. Thirdly, this place was a borderland between Kazakhs and Kirgiz, which is consistent with the discussion above.

To locate the place of Šarabel (Saribel) with greater precicion, we need to rely on more concrete information. Fortunately, the Manchu archival documents concerning the "frontier patrols" of Qing detachments in the Tarbagatai Mountains and the region south of Lake Balkash in the early 1760 s provide such information. It needs to be pointed out here that, in connection with studies of the so-called "Qing frontier patrolling system” (清代新疆巡邊制度), some opinions have been offered about the location of Šarabel (Sarïbel). For example, Li Sheng 厉声 identifies Šarabel as Karabalta; ${ }^{66}$ Onuma Takahiro 小沼孝博 says there is a possibilty that Šarabel could be Sa- 
ribulaq to the north of Kara-balta. ${ }^{67}$ But both of these opinions are hypotheses without concrete proof. So we need to further investigate the problem by going back to the relevant Manchu language historical sources.

Of the sources the most interesting one is the "secret" Qing map I mentioned above in note $4 .{ }^{68}$ In this "secret" Qing map there appears a separate mountain (alin in Manchu) called Šarabel, and its location can be described roughly as follows: it was northeast of the Aršatu-Cagan River and northwest of Kugurik Mountain; it was at the south of the mountain from which originates two tributaries of the Kuitun River. According to the map, Šarabel stretches as a separate mountain roughly from northwest to southeast and connects with the Kugurik Mountain, oriented in an east-west direction.

It would at first appear that problems concerning the location of Šarabel (Sarïbel) could be definitively resolved by consulting this map. But comparing the information given in the map with that preserved in some Qing palace memorials about the implementation of "frontier patrols" at the end of 1763 and the beginning of 1764, we find that there are still questions about the definition and scope of the place. The following sources present puzzles:

In one of his palace memorials to Qianlong, Mingšui, the Ili jiangjun, wrote: "Iletu the councilor went out to patrol places such as Chui and Šarabel . . . Iletu met Udai ${ }^{69}$ at Šarabel." ${ }^{70}$ However, in another palace memorial, Mingšui mentioned that "[Iletu] arrived at the Haštak (< Kastek) mountain pass (Manchu dabagan) and met with Udai on the 4th day of the 12th month (January 6, 1764)." ${ }^{.1}$

In a palace memorial submitted by Našitong, the councilor in Kashgar, we read: "When Udai went out to patrol Temurtu-noor (= Issik-köl Lake) and other places, he met thirty Muslims from Kashgar led by Anjubai at the Kuitun-Kuretu place of Šarabel." ${ }^{2}$

The Chinese transcriptions of almost all of the above-mentioned place names (except that of Šarabel) can be found on the Qianlong Map. I identify the relevant place names as follows: ${ }^{73}$ 1) Aershatu bila 阿爾沙圖比拉 = Aršatu-Cagan River on the "se-

究, ed. Ma Dazheng 馬大正 et al. (Urumchi: Xinjiang renmin chubanshe, 1994), 413.

67. Onuma, Shin to Chūō Ajia sōgen, 248.

68. As noted above, two Manchu memorials mention that copies of a Manchu map were delivered to Qing border generals in the spring of 1761. In July 2013, I noticed that a Manchu map had been released on the Information Management Platform of the First Historical Archives of China, and by reading the content of the map, I concluded that it is the very map mentioned in those two Manchu documents. The information I give here is from the notes I took in the archives in 2013. (In accordance with First Historical Archives policies, I could not copy the map itself).

69. The lingdui-dachen commanding the Qing patrol detachment followed a southern route: departing from Ili, the detachment crossed the Musur (Muzart) Pass, crossed the southern shore of Temurtu-noor (=Lake Issik-köl), and then turned north to the Šarabel and Chu regions. Another Qing detachment led by Councilor (canzan-dachen) Iletu took a northern route crossing the Ili River and the Gürban-Alimatu ("Three Almaty"), and then headed to the Šarabel and Chu regions. See the Manchu archival documentation cited below.

70. QZHGDH, 2: 467-70, No. 167.

71. QZHGDH, 2: 527-29, No. 187.

72. QZHGDH, 2: 545-47, No. 195.

73. See Map No. 5, with numbers marking the relevant place names. 


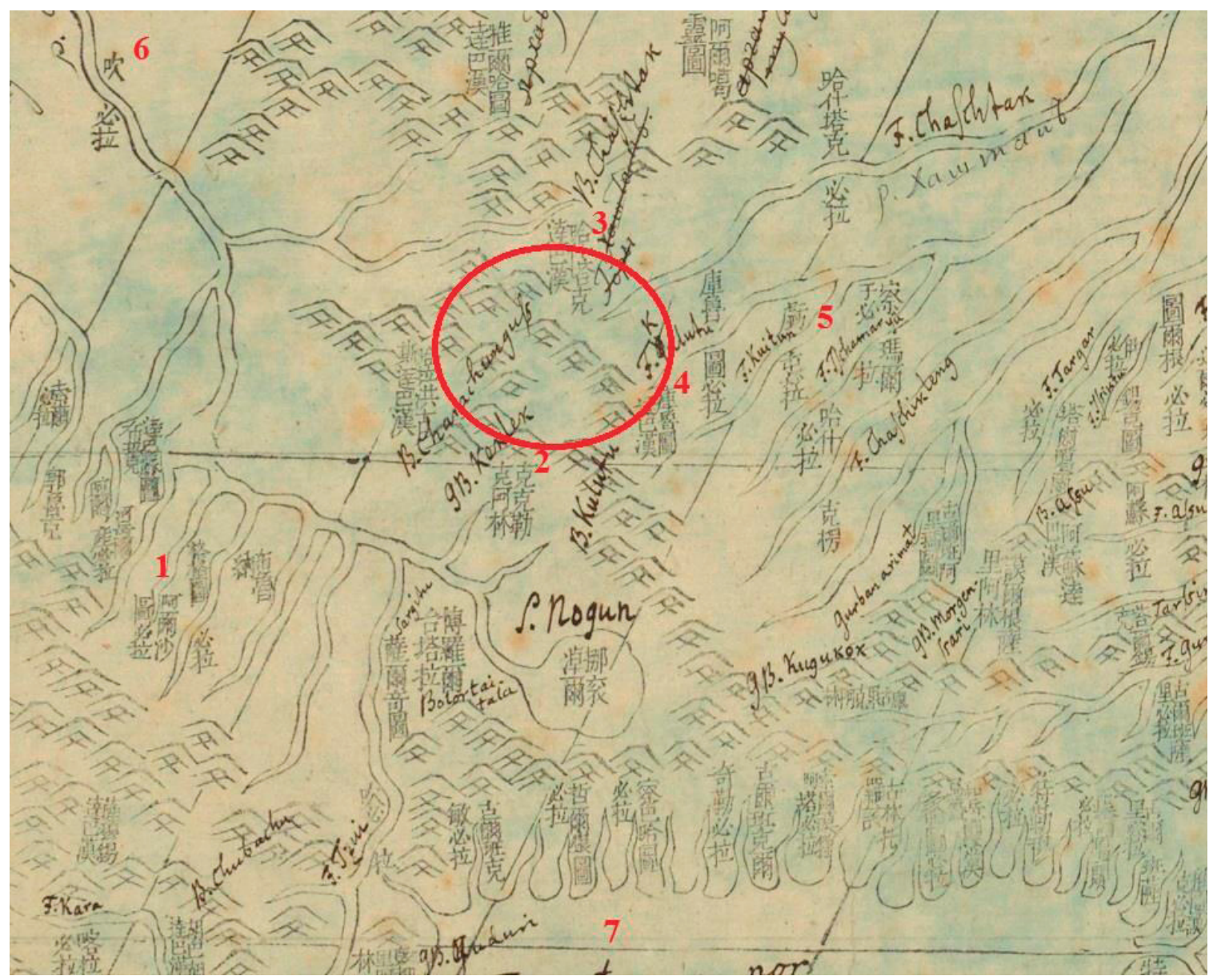

Map No. 5: “Qianlong map” (detail 2). Source: BnF, GE D 25949 (1) RES.

cret” Qing map; ${ }^{74}$ 2) Kekeleke alin 克克勒克阿林 = Kugurik Mountain on the “secret” Qing map; ${ }^{75}$ 3) Hashitake dabahan 哈什塔克達巴漢 $=$ Haštak $^{76}$ mountain pass in Mingšui's palace memorial; 4) Kulutu 庫魯圖77 = Kuretu in Našitong’s palace memorial; ${ }^{78}$ 5) Kuitun bila 虧屯必拉 = Kuitun in Našitong’s palace memorial;79 6) Chui bila 吹必拉 = Chui in the Manchu documents, namely the Chu River; 7) Tiemuertu noer $=$ Temirtu noor in the Manchu documents, namely the Issik-köl Lake.

Synthesizing the information given above, I conclude that, instead of being one separate mountain range as shown on the "secret" Qing map, Šarabel is a major area

74. The Kazakh and Kirgiz now call this river Aršatï.

75. Kazakhs now call this mountain Keklik, and this proves that the Manchu form ("Kugurik") of the name on the "secret"

Qing map is a corruption, while the transcription on the Qianlong Map is closer to its original form.

76. Following its modern Kazakh pronunciation, the mountain pass should be called Kastek.

77. According to the Qianlong Map, there are two places that bear this name: one is a river, and another is a mountain pass.

78. Based on its modern form, it would seem that the more proper pronunciation of this place name was "Kürti."

79. A place near Kastek Pass is now named Suwiq töbe ("Cold hill") in Kazakh. This name may have something to do with Kuitun, which also means "cold" in Mongolian. 
that consists of these places (as annotated with a red circle on Map No. 5 above): to the east - the origin of the Kurtu (< Kürti) River; to the south - Kekliik Mountain and the source of the Kuitun River (I identify it with modern Suwïq-töbe mountain); to the north - Kastek Pass. This means that, according to Abulai Khan's understanding, the southern boundary (ujan) of Kazakh pasturelands in 1760 was not far from the modern Kazakh-Kirgiz border.

\section{Conclusion}

As pointed out in the introduction of this article, the depiction of the region east and south of Lake Balkash primarily as an object of bipolar territorial rivalry between the Qing Empire and Russia starting in 1760 completely ignores the relevance of Kazakhs, the actual residents of the territory, to the sovereignty issue. This is, first of all, an anachronism, because Russian colonial rule in its true sense was not yet established in the Kazakh steppe. The letter analyzed here and the relevant sources concerning the background to this document show that there did indeed emerge a bipolar territorial rivalry as early as the 1760s, but the party facing the Qing was not Russia but Kazakhs.

The content of the letter by the Kazakh khan Abulai to the Qing court in 1760 recalls the fact that, when the first Kazakh envoys put forward their claim of sovereignty over the Tarbagatai region in the autumn of 1757, the Qianlong emperor treated the issue only as a bargaining chip in negotiating with the Kazakhs, rather than making a definitive rejection. This reveals that the Qing rulers, who would map their western frontier in the 1760s, did not yet have a clear sense of these lands in 1757. Qing policy became more assertive in the 1760s, when the so-called Hasake jecen was already set flatly to the west of Lake Balkash. The historical sources the Qing court relied on when it designed this new policy are unclear, ${ }^{80}$ but it is safe to say that, although the Qing-Kazakh relationship in the 1760s might have differed from that in 1757-1758, there was no indication that the actual ownership of this territory shifted away from the Kazakhs to Qing forces or even to Oirat (Elute) remnants in that time period. The basis of the new Qing policy concerning this territory must have been Qianlong's conceptualization that the Qing empire should master all lands on which the Oirats (Elute 厄魯特 in Qing Chinese, and Kalmaki on von Strahlenberg's map) had once set foot - a conceptualization quite questionable, not only because it is inconsistent with the

80. I tend to suppose that the policy had some kind of causal association to Nusan's referenced above in n4. Still, to conclusively prove such a supposition, further comparison of the relevant sources is necessary, especially with some of the "secret maps" drawn in 1750s and 1760s by Qing authors. I hope that these will be released in the future. 
historical facts ${ }^{81}$ but also because it conflicts with how Kazakhs understood ownership of those lands in the second half of eighteenth century.

From the information given in Abulai Khan's letter to the Qing court in 1760, we learn that, just as Qing imperial policy concerning eastern Kazakh territory was forming and the Qing court was trying to restrict Kazakhs to the western side of its unilaterally conceived Hasak jecen ("Kazakh border") of Ayagus - Balkash - Chu, Kazakhs led by Abulai Khan had their own ideas about who possessed the territory east and south of Lake Balkash. By showing the ujan (boundary) in the east and south, they also sketched out a jecen of their pasturelands. This reached east to Chorgo, the eastern branch of the Tarbagatai mountain range, which penetrates into modern Emin 額敏county (its local Kazakh-Mongolian name is "Dörbeljïn") and now forms a part of the border between the Republic of Kazakhstan and the People's Republic of China, and reached south to Šarabel (Kaz. Sarïbel), a major area near the Kastek mountain pass and also not far from the modern Kazakh-Kirgiz border. The Kazakhs urged the Qing emperor to send a red-sealed edict officially approving this jecen. Although the "border" in this area, in its modern sense, came into being only in the second half of the nineteenth century, the rough match between Abulai Khan's eastern and southern boundaries for Kazakh lands and the modern Kazakh-China and Kazakh-Kirgiz borders, suggests a strong influence of Abulai Khan's Kazakhs on current borderlines.

\section{Acknowledgments}

I would like to thank Virginia Martin (University of Wisconsin-Madison) for her help throughout the process of finalizing this article. Thanks also to the Fulbright Visiting Scholar program under which I developed my early ideas about this article in 20132014. I am grateful to the peer reviewers who offered valuable suggestions and to Matthew Mosca, who kindly sent me the scholarly material I needed for revisions after submitting an early version to Saksaha. And thanks for the English editing work done by Matthew Mosca and Brian Vivier.

\section{Bibliography}

Академу наук СССР, Институт Языкознания. Древнетюркский словарь [A Dictionary of Old Turkic]. Денинград: “Наука,” Ленингр. отд-ние, 1969.

81. As mentioned above, one of the early Kazakh claims put forward by the first Kazakh mission to the Qing court dealt only with the historical ownership of the Tarbagatai region by Kazakhs. While this fact seemed never to have come to the minds of Qing rulers and scribes — Zhetïs ("Seven Rivers") had been the very cradle and base for the Kazakh khanate before the second half of the seventeenth century. 
Bahati Yijiahan 巴哈提 依加漢 [B. Ezhenkhan-uli]. “Xi Qing wenxian suoji “Hasake Xibu”析清 文獻所記“哈薩克西部”[Analysis of the“Western Part of Kazakhs” in Qing Sources]. Yuanshi ji beifang minzushi yanjiu 元史及北方民族史集刊 11 (1987): 83-87.

Boxihe 伯希和 [Paul Pelliot]. Ka'ermeikeshi pingzhu 卡尔梅克史评注. Translated by Geng Sheng 耿 昇. Beijing: Zhonghua shuju, 1994.

Daqing Gaozong Chun (Qianlong) Huangdi Shilu 大清高宗純（乾隆）皇帝實錄 [The Veritable Records of the Qianlong Emperor of the Great Qing Dynasty]. Compiled by Qinggui 慶桂et al. 1807. Reprint, Beijing: Zhonghua shuju, 1986. Abbreviated GZSL.

Daqing Shizong Xian (Yongzheng) huangdi shilu 大清世宗憲（雍正）皇帝實錄 [The Veritable Records of the Yongzheng Emperor of the Great Qing Dynasty]. Beijing: Zhonghua shuju, 1986.

Еженханұлы, Б. Қазақ хандығы мен Цин патшалығының саяси-дипломатиялық байланыстары туралы қытай мұрағат құжаттары [Chinese Archival Documents on the Political and Diplomatic Relationships between the Kazakh Khanate and the Qing Court]. 3 vols. Алматы: «Дайкпресс», 2009.

. “Қазақ үш жүзінің шеткері жерлеріндегі жер атаулары» атты Цин патшалық мұрағат құжатына тарихи-деректанулық талдаулар" [Historic-geographical Studies on the Qing Archival Document The Place Names of the Borderlands of Kazakhs' Three Hordes]. Қазақстан республикасының Ұлттық ғылым академиясының ХАБАРЛАРЫ 2 (2013): 28-35.

. Қожаберген батыр - 1756-1767 жылдарда қалыптасқан мәнжу-қытай мұрағат құжаттары негізінде [Khojabergen Batï - Based on the Manchu-Chinese Archival Documents of 1756-1767]. Алматы: Арыс баспасы, 2017.

. See also Bahati Yijiahan 巴哈提 依加漢.

, Ж. Ошан, and С. Сұңғатай. Қазақстан туралы қытай дереутеселері [Chinese Historical Sources concerning the History of Kazakhstan]. 5 vols. Алматы: Цин патшалық мұрағат құжаттары, 2005-2006.

Fairbank, John King. "A Preliminary Framework.” In The Chinese World Order: Traditional China's Foreign Relations, ed. Fairbank, pp. 1-19. Cambridge, Mass.: Harvard University Press, 1968.

Fuheng 傅恆 et al., editors. Huangqing zhigong tu 皇清職貢圖. Shenyang: Liaoshen shushe, 1991. . Xiyu tongwenzhi 西域同文志 [A Comparative Glossary of the Languages in Western Regions]. Edited by Wu Fengpei 吳豐培. Minzu guji congshu 民族古籍叢書 ed., Beijing: Zhongyang minzu chunbanshe, 1984. Abbreviated XTZ.

. Xiyu tuzhi jiaozhu 西域圖志校注 [Gazetteer of the Western Regions, Edited and Annotated]. Edited by Zhong Xingqi 鐘興麒 et al. Urumqi: Xinjiang renming chubanshe, 2002. Abbreviated XT.

Gorelova, L. M. Manchu Grammar. Leiden: Brill, 2002.

Junjichu Manwen lufu zouzhe 軍機處滿文錄副奏摺 [Reference copies of Palace Memorials, in Manchu in the Grand Council]. First Historical Archives of China, Beijing. Abbreviated JMLZ.

Қазақ ССР Ғылым академиясы Тіл мен әдебиет институты. Қазақ тілінің түсіндірме сөздігі [An Explanatory Dictionary of Kazakh]. Алматы, 1959.

Li Sheng 厉声. “Qingdai Xinjiang xunbian zhidu yanjiu” 清代新疆巡边制度研究 [Studies on the Frontier Patrolling System in Qing Dynasty Period]. In Xiyu kaocha yu yanjiu 西域考察与研究, edited by Ma Dazheng 馬大正 et al., pp. 406-25. Urumchi: Xinjiang renmin chubanshe, 1994.

. Hasakesitan jiqi yu Zhongguo Xinjiang de guanxi: 15 shiji-20 shiji zhongqi 哈萨克斯坦及 其与中国新疆的关系：15世纪-20世纪中期 [Kazakhstan and Its Relations with China regarding Xinjiang: Fifteenth to the mid-Twentieth Centuries]. Harbin: Heilongjiang jiaoyu chubanshe, 2004.

Noda, Jin. The Kazakh Khanates between the Russian and Qing Empires: Central Eurasian International Relations during the Eighteenth and Nineteenth Centuries. Leiden: Brill, 2016. 
and Onuma Takahiro. A Collection of Documents from the Kazakh Sultans to the Qing Dynasty. Tokyo: Department of Islamic Area Studies, Center for Evolving Humanities, University of Tokyo, 2010.

Norman, Jerry. A Comprehensive Manchu-English Dictionary. Cambridge, Mass.: Harvard University Asia Center, 2013.

Onuma Takahiro 小沼孝博. Shin to Chūō Ajia sōgen: Yübokumin no sekai kara teikoku no henkyōe e清と 中央アジア草原: 遊牧民の世界から帝国の辺境へ [The Qing and the Central Asian Steppe: From the World of Nomads to the Frontier of Empire]. Tokyo: Tokyo daigaku shuppankai, 2014.

Perdue, Peter C. "Boundaries, Maps, and Movement: Chinese, Russian, and Mongolian Empires in Early Modern Central Eurasia." The International History Review 20.2 (June 1998): 263-86.

China Marches West: The Qing Conquest of Central Eurasia. Cambridge, Mass.: Harvard University Press, 2005.

Pingding Zhungaer fanglüe 平定準噶爾方略 [Records of the Pacification of the Zunghar]. Compiled by Fuheng 傅恒 et al. Edited by Xizang shehui kexueyuan Xizangxue Hanwen wenxian bianjishi 西藏社會科學院西藏學漢文文獻編輯室. Beijing: Quanguo tushuguan wenxian suowei fuzhi zhongxin, 1990.

Ramstedt, G. J. Введение в алтайское языкознание [Introduction to Studies of the Mongolian Language]. Москва: Изд-во иностранной лит-ры, 1957.

Saguchi Tōru 佐口透. 18-19 seiki Higashi Torukisutan shakaishi kenkyū 18-19世紀東トルキスタン 社会史研究 [Studies in the social history of Eastern Turkistan in the 18-19th centuries]. Tōkyō: Yoshikawa kōbunkan, 1963.

Shinkyō minzokushi kenkyū 新疆民族史研究 [Studies on the History of the Peoples of Xinjiang]. Tokyo: Yoshikawa kōbunkan, 1986.

Shi Yuxin 史宇新. “Bohuangyan zhizaozhe一guanyu Zhong-Su bianjie de ruogan wenti” 驳谎言制造 者一关于中苏边界的若干问题 [Veto to the Liars - on Some Problems concerning Sino-Soviet Borders]. Lishi yanjiu 历史研究 1974.1: 113-28.

Sinor, D., and S. G. Klyashtorny. "The Türk Empire.” In History of Civilizations of Central Asia. Vol. III, The Crossroads of Civilizations: A.D. 250 to 750, edited by B. A. Litvinsky, Zhang Guang-da, and R. Shabani Samghabadi, pp. 327-47. Paris: UNESCO Publishing, 1996.

Songyun 松筠. Qinding Xinjiang shilüe 欽定新疆識略 [Imperial Commissioned Gazetteer of Xinjiang]. Wuyingdian 武英殿 edition, 1821. Abbreviated XJShL.

Валиханов, Ч. Ч. Собрание сочинений в пяти томах. Алма-Ата: Glav. Red. Kazakhskoi sob. Entsiklopedii, 1984.

von Strahlenberg, Philip John. An Historico-Geographical Description of the North and Eastern Part of Europe and Asia; but More Particularly of Russia, Siberia, and Great Tartary both in Their Ancient and Modern State: together with an Entire New Polyglot Table of the Dialects of 32 Tartarian Nations... Faithfully Translated into English. London: W. Innys and R. Manby, 1738.

Wang Qianjin 汪前進and Liu Ruofang 劉若芳, editors. Qingting san da shice quantuji 清廷三大實 測全圖集 [Comprehensive Collection of the Qing Court's Three Grand Maps Drawn by Actual Measurement]. Beijing: Waiwen chubanshe, 2007.

Zhongguo diyi lishi dang'anguan 中國第一歷史檔案館 and Hasake Dongfangxue yanjiusuo 哈薩 克東方學研究所, editors. Qingdai Zhong-Ha guanxi dang'an huibian 清代中哈關係檔案彙編 [Archival Documents concerning Sino-Kazakh Relationships during the Qing Dynasty]. Beijing: Zhongguo dang'an chubanshe, 2006-2007. Abbreviated QZHGDH.

Zhongguo diyi lishi dang'anguan 中國第一歷史檔案館 and Zhongguo bianjiang shidi yanjiu zhongxin 中國邊疆史地研究中心, editors. Qingdai bianjiang Manwen dang'an mulu 清代邊疆 滿文檔案目錄. Guiling: Guangxi shifan daxue chubanshe, 1999. Abbreviated QBMDM. 
Qingdai Xinjiang Manwen dang'an huibian 清代新疆滿文檔案彙編 [Collection of Manchu Archival Documents about Qing-era Xinjiang]. Guilin: Guangxi shifan daxue chubanshe, 2012. Abbreviated QXMDH.

Zhongguo jin-xiandaishi 中國近現代史 [A History of Early Modern and Modern China]. Beijing: Renming jiaoyu chubanshe, 2002. 